\title{
THE STRANGE CASE OF TEACHING ENGLISH THROUGH THE GOTHIC NOVEL
}

\author{
Simona Maggi
}

Independent Scholar

\begin{abstract}
In this article I endeavour to encourage teachers of Secondary Education to use English literature in their English language lessons. Indeed, literature provides a huge amount of authentic reading materials, making the students practise extensive as well as intensive reading, which is crucial for the foreign language acquisition. Moreover, it is an enormous source of motivation, allowing students to give free rein to their imagination and enjoy their English lessons. The election of gothic fiction is linked to this latter purpose: the $19^{\text {th }}$ gothic genre is generally well accepted by adolescents as it represents a way to reflect on themselves through a journey to "self-revelation". The double personality/identity-theme of R. L. Stevenson's novel The Strange Case of Dr Jekyll and Mr Hyde fits well into their interests and their quest for self-knowledge. It offers them the chance to process what they are going through in this often unstable stage of their journey into adulthood by trying to figure out their place in the world.
\end{abstract}

Key words: Reading skill, Literature in ELT, Gothic fiction, R. L. Stevenson, The Strange Case of Dr Jekyll and Mr Hyde, Double identity

\section{Resumen}

En este artículo pretendo alentar a los profesores de educación secundaria a emplear la literatura inglesa en sus clases de inglés. La literatura proporciona una gran cantidad de materiales de lectura auténticos, lo que hace que los estudiantes practiquen tanto la lectura de todo tipo de textos como el análisis minucioso de algún texto en particular, lo cual es crucial para la adquisición del idioma extranjero. Además representa una enorme fuente de motivación, permitiendo a los estudiantes liberar su imaginación y disfrutar de las clases de inglés. La elección de la novela gótica está vinculada a este último propósito: el género gótico del siglo XIX es generalmente bien aceptado por los adolescentes. Se identifican con el género gótico porqué representa una forma de reflejarse en sí mismos a través de un viaje hacia la "autorrevelación”. El tema de la doble personalidad/identidad de 
la novela The Strange Case of Dr Jekyll and Mr Hyde de R. L. Stevenson encaja con sus intereses y su busca del autoconocimiento. Les ofrece la oportunidad de procesar lo que están viviendo en esta inestable etapa de su viaje a la madurez, tratando de descubrir su lugar en el mundo.

Palabras clave: enseñanza de la lectura, enseñanza del inglés a través de la literatura, novela gótica, R. L. Stevenson, The Strange Case of Dr Jekyll and Mr Hyde, doble identidad

\section{Literature in foreign language teaching}

The role of literature in the second/foreign language classroom has traditionally had an intermittent presence throughout the history of EFLT, varying in intensity according to the different methodologies or approaches applied to the language teaching. Only fairly recently has it gained a new level of importance in natural association with the reading experience and the acquisition of the reading competence. Indeed, reading literature in ELT has of late gained a higher value among scholars, teachers and students as they have come to realise that it presents numerous advantages for the acquisition of the second/foreign language. Literature provides an assorted range of authentic texts and exposes students to different types of language, it broadens the students' minds by stimulating their imagination and a more mature perception of other cosmologies; it also motivates them to practise the reading skill through a wide range of appealing topics.

"How can I hope to explain Literature to you, with its capital 'L'?", Fay Weldon asks Alice, an imaginary niece, in his work Letters to Alice on First Reading Jane Austen. Weldon tries to convince the young girl, who belongs to a generation absorbed by the universe of discos and television, to read literature "before it's too late" (10). In the first chapter the author gives a revealing description of the literary universe defined as a "City of Invention", where every writer builds his/her own "House of Imagination":

Let me give you, let me share with you the City of Invention. For what novelists do (I have decided, for the purpose of your conversion) is to build Houses of Imagination, and where houses cluster together there is a city. And what a city this one is, Alice! It is the nearest we poor mortals can get to the Celestial City: it glitters and glances with life, and gossip, and colour, and fantasy: it is brilliant, it is illuminated, by day the sun of enthusiasm and by night the moon of inspiration. It has its towers and pinnacles, its commanding heights and its swooning depth: it has public 
buildings and worthy ancient monuments, which some find boring and others magnificent. It has its central districts and its suburbs, some salubrious, some seedy, some safe, some frightening. This who founded it, who is to this city that the readers come, to admire, to learn, to marvel and explore. (11)

This book, apart from attempting to bring some thoughtful insights to the work of Jane Austen in particular, endeavours to provide an answer to those who question the relevance of literature in general. By presenting the three aforementioned metaphors (City of Invention, Houses of Imagination, Celestial City) Weldon drives his niece through the magnificent books which form the literary universe, thus providing her with a definition of literature. He also drives the readership to the double dilemma of whether the literary universe is worth being taught at school or not, and whether EL teachers should teach literature and train students in the literary competence or just in the linguistic one instead. Indeed, according to Brumfit and Carter, "[Literature] offers a context in which exploration and discussion of content (which if appropriately selected can be an important motivation for study) lead on naturally to examination language" (15). According to them, linguistic competence and literary competence can (and should) go hand in hand in the acquisition of a second/foreign language. The concept of literary competence is closely knit to the learning of literature as a formative process of the student. S/he aims to "read" literary texts by accepting the literary features that may characterize them, with the purpose, among others, of learning how to analyse and apprehend them and be able to finally express a critical judgement on them (Caon and Spaliviero 18). In other words, the modern EFL models see literary texts as useful and valid resources to actively involve students and foster in them a number of active and positive attitudes towards the target language, literature and culture.

No one doubts nowadays that literary texts provide authentic language, i.e. real language in context as created by a native writer for a native readership. But this current unanimous belief has not always been so unanimous among scholars. The relationship between English literature and ELT has always been a rather difficult marriage and a controversial issue. Teachers are often influenced by curriculum constraints and usually experiment a lack of faith in literature as a means of teaching because they consider it as inferior to achieving the main goal of teaching grammar or because of the difficulty that is usually inherent in literary texts as they usually reproduce cultural aspects that may not always be easily understood by a younger type of student. On the contrary, literature should be perceived and conveyed as an invaluable resource of motivating material and as a bridge to provide access to the cultural background of the language studied. Literature encour- 
ages language acquisition, expands the students' language awareness and interpretation abilities and it educates the whole person (Lazar 1993, cited in Banegas 2-3). Collie and Slater (1987, cited in Banegas 2) support the inclusion of literature in the language classroom as it provides a valuable source of authentic material, develops personal involvement and helps to contribute the reader's cultural and language enrichment.

If it is assumed that literature is a body of written works which have an artistic or intellectual value (due to its Latin root "littera", which means letter or handwriting), according to Bruner (cited in Giusti 4), a literary text is capable of stimulating the reader's imagination through a mental representation of what is read. Literature is a very strong cognitive and cultural instrument with which it is not only possible to give a meaning to the human actions and intentions but also to build and explore all the possibilities and negotiate one's own social and personal identity. Literature is a cultural instrument, a forum in which the values of a defined social group are negotiated (10).

The answer to the question "why should we use literature in English language teaching?" would therefore be: because it promotes reading (either intensive or extensive), it stimulates motivation in learning English and improves the communicative competence as well as the cultural and the intercultural awareness. According to Demetriou and Ruiz Mas (91), literature exposes learners to other cultures broadening their minds and teaching how to respect "otherness". It also increases the linguistic knowledge by introducing learners to a much "varied range of contexts and situations that would be difficult to reproduce faithfully in the daily practice classroom" (91). So, it contributes not only to the acquisition of grammar knowledge but also to the development of the four skills. One may think that literature is mainly reading, and it is; but the rest of the skills can and should also be practised: speaking can be trained by reciting poems, performing drama or singing songs; listening can be fostered through the oral narration of tales, songs, watching a play, or attending poem recitations; writing can be practised through short stories, descriptions or dialogues (91), etc.

Moreover, literature provides a world which stimulates students' imagination and creativity as they have to recreate mentally what they have read and infer meaning. It also provides a universe of characters with which students cannot help being identified, making them feel "motivated to learn the language if they feel their own world is represented in front of them" (91). The Common European Framework of Reference for Languages (CEFRL) also defends the imaginative and artistic use of language which is educationally significant. This approach of language teaching is embodied by productive, receptive, interactive or mediating (oral and written) tasks. With certainty, literature is seen as a productive resource 
which may be exploited in several ways, providing a wide range of activities like singing, storytelling, creative writing, performing scripted or unscripted plays, listening to imaginative texts, etc. (CEFRL 56).

About the authenticity of the literary texts Brumfit and Carter affirm that,

A literary text is authentic text, real language in context, to which we can respond directly. It offers a context in which exploration and discussion of content (which if appropriately selected can be an important motivation for study) leads on naturally to examination of language. (15)

So literary texts provide learners with a genuine production of language that would serve as a better example of how natives of the target language communicate verbally in a multiplicity of situations, as previously stated. On this topic Littlewood argues that:

A major problem of language teaching in the classroom is the creation of an authentic situation for language. A language classroom especially one outside the community of native speakers, is isolated from the context of events and situations which produce natural language. In the case of literature, language creates its own context. (179)

The CEFRL also defends the idea that national and regional literatures contribute to the European cultural heritage, which the Council of Europe regards as "a valuable common resource to be protected and developed" (56). It states that "literary studies also serve many more educational purposes - intellectual, moral and emotional, linguistic and cultural - than the purely aesthetic" (56). The multiple advantages of introducing literature in the language classroom are once again confirmed. Literature is one of the cultural manifestations of a defined social group in a certain period of time and acquiring a language without its culture is unconceivable. McKay argues that "literature may work to promote a greater tolerance for cultural differences for both the teacher and the student" (193). Fenner goes further by stating that "literature does not only represent contemporary foreign culture: it also represents the past" (20). On aspects related to intercultural awareness, Fenner also states that,

Knowledge, awareness and understanding of the relation (similarities and distinctive differences) between the "world of origin" and the "world of the target community" produce an intercultural awareness. It is, of course, important to note that intercultural awareness includes an awareness of regional and social diversity in both worlds. It is also enriched by awareness of a wider range of cultures than those carried by the learner's L1 and L2. This wider awareness helps to place both in context. (103) 
In other words, literature, by bringing students closer to the past cultures that still influence our modern societies, leads them to a major understanding of the contemporary foreign cultures, thus improving plurilingualism and fostering interculturality. In this respect, the CEFRL affirms that,

The linguistic and cultural competences in respect of each language are modified by knowledge of the other and contribute to the intercultural awareness, skills and know-how. They enable the individual to develop an enriched, more complex personality and an enhanced capacity for further language learning and greater openness to new cultural experiences. (CEFRL 43)

Language is not only a tool of communication but also an instrument to come closer to another culture, its customs and its values. So literary texts in the target language provide learners with the cultural knowledge they have to assimilate in order to eventually become fluent speakers. In Weldon's words, "it is in the literature, the novels, the fantasy, the fiction of the past, that you find real history, and not in the textbooks" (13).

Following Giusti (4), speaking about the literary text, it is "uno strumento cognitivo e culturale col quale e' possibile dare un senso alle azioni e intenzioni umane, ma anche costruire e esplorare mondi possibili, negoziare il proprio ruolo sociale e la propria identità". And he continues:

la letteratura non e' solo un magazzino di storie. La letteratura può essere considerata a sua volta un testo, una storia che viene continuamente narrata dai membri di una comunità, i quali negoziano il significato e il valore dei singoli testi sulla base della storia che li tiene insieme. In questo senso la letteratura e' uno strumento culturale, un forum all'interno del quale vengono negoziati i valori di un gruppo sociale. (10)

To sum up, apart from the many advantages already mentioned for the development of the skill of reading and for the improvement of the language acquisition, literature is not just a storehouse of stories; it can be considered a text itself which the members of a certain community continually narrate in a certain society and in a certain time. Literature is therefore a cultural tool, a forum within which the values of a given social group are negotiated. Literature is part of the culture of its speakers and learning a language also includes learning its culture, where literature represents one of its highest manifestations. 


\section{Teaching gothic literature}

Why teach English to adolescents through Gothic fiction? Gothic literature is a literary genre that combines fiction and horror, death and more often than not romance too. Gothicism easily mirrors the contradictions which teenagers go through in that delicate period of their lives. Gothic literature fascinates teenagers as it offers the chance to process what they are going through, combining romantic emotions with the most proscribed and unexplored feelings.

According to Fred Botting, Gothic is characterized by excess, transgression and diffusion. In his work Gothic, he describes its main features of the genre and explains why from being an often mocked genre and an easy target for satire at the beginning it started to enjoy a level of popularity that has prevailed up to the present times. Gothic represents excess as it depicts the contradiction of the eighteenth century society by opposing rationality and morality with irrationality, the supernatural and social transgression, where passion and excitement offend the moral laws: "It shadows the despairing ecstasies of Romantic ideals and individualism and the uncanny dualities of Victorian realism and decadence" (1).

The Gothic genre reveals what is rejected, what disturbs the cultural establishment, its values and beliefs. Initially it was a reaction against the eighteenthcentury Enlightenment's views of the world, stubbornly organized and defined by reason, logic and categorization. The Gothic genre started as a literary reaction to the inadequacy controlling the irrationality of the human soul. It represented the irrepressible and the unspeakable struggle against "the limitations to Enlightenment rationality which claimed to elevating humanity through science" (Yang and Healey 4). The cultural anxieties were embodied through Gothic landscapes, thus going beyond the mere scenery of the main action. Decaying architecture, dark labyrinths, subterranean passages, frightening interiors, storms, fog, gloomy forests, medieval ruins, crumbling castles and abbeys reflected the social darkness, the chaos of a culture in transition. According to Valdine Clemens, "when reason and science usurped God, Gothic rushed in to fill the resulting vacuum with the daemonic" (cited in Yang and Healey 4).

Gothic is also based on feelings and emotions associated with the sublime. In 1759 the Irish political theorist and philosopher Edmund Burke published a philosophical essay on aesthetics, A Philosophical Enquiry into the Origin of our Ideas of the Sublime and Beautiful. Burke was unaware that it would be of the utmost importance in the development of the English fiction later on in the century. Burke provided a definition of the sublime by dividing its effects into a major one, astonishment, and inferior ones, admiration, reverence and respect, to conclude that it was based on terror. Whatever is terrible or great in dimension is sublime because it arouses a sense of danger and terror. But two conditions are 
essential: obscurity and mystery. Among the causes of the sublime he mentions the idea of pain and death inflicted by a superior power and four sources which convey thrills and emotions to the reader's mind: strength, violence, pain and terror. Reflecting upon his concept of the beautiful and the sublime, his work served as a source of inspiration for the future Gothic novelists and paved the way for the new spirit of Romanticism.

The excesses and the ambivalence associated to Gothic fictional protagonists are seen as elements of transgression, but breaking the social and the aesthetic limits serves to reinforce the value and to restore the limits. The Gothic heroes and heroines, after having experimented excess and transgressed limits, finally restore the moral and social order:

Gothic terrors and horrors emanate from reader's identification with heroes and heroine: after escaping the monsters and penetrating the forest, subterranean of narrative labyrinths of the Gothic nightmare, heroines and readers manage to return with an elevated sense of identity to the solid realities of justice, morality and social order. (Botting 5)

For this reason, even presenting models of excessive feelings such as revenge, prohibited love or transgression, Gothic literature, far from inducing young readers/teenagers to act like the unbalanced characters depicted by the novels, constitutes an excellent source to catch the students' attention. By identifying themselves with the characters, students can see the consequences of the transgression and of dealing with negative emotions, thus inciting them to learn from them and channel their feelings in a positive way.

According to Botting (5), many of the anxieties in Gothic terms have reappeared throughout the centuries and this has helped to perpetuate the tradition; but what gave it its great and definitive popularity was the development of the cinematographic production at the beginning of the 20th century. Vampires, Jekylls and Hydes, Frankensteins and monsters have populated cinema and televisions screens all over the world, sometimes assuming the pretense of sinister characters, sometimes pushing the limits of the ridiculous:

The diffusion of Gothic features across texts and historical periods distinguishes the Gothic as a hybrid form, incorporating and transforming other literary forms as well as developing and changing its own conventions in relation to newer modes of writing. (9)

The aesthetic and moral worth of Gothicism as a literary/artistic genre has often been discredited, but the vivid imagery of the genre involving extremes of human endurance catches undoubtedly the students' attention and the influence of Gothic literature in ELT is currently confirmed by the amount of graded readers 
based on Gothic novels which are made available by publishers in their yearly ELT catalogues, thus reinforcing their validity for teaching English and the success of the genre at every level of the EL learning process. Indeed, the most frequently adapted Gothic or gothic-like novels as graded readers are Mary Shelley's Frankenstein, Charlotte Brontë's Jane Eyre, Emily Brontë's Wuthering Heights, Bram Stoker's Dracula, R. L. Stevenson's The Strange Case of Dr Jekyll and Mr Hyde and E. A. Poe's Tales of Horror and Imagination, all of which happen to stay out of the publishers' obligation to pay copyrights to their respective $19^{\text {th }}$ century authors. Rodabaugh (1996) lists five themes that adolescents and Gothic literature have in common: extreme emotions, the journey of self-revelation, the individual against the unknown, the rebellion against the authority, transgression and sympathy for the outcasts. Learning about Gothic literature allows students to think and to go deeper into their own feelings; it provides them with a way to reflect on themselves. They are attracted to it, as many characteristics which are inherent to the Gothic genre are also the characteristic of the period of adolescence. This is why Gothic genres have become so popular even nowadays, especially among teenagers. Kelly Hurley describes Gothic as "a cyclical genre that reemerges in times of cultural stress in order to negotiate anxieties for its readership by working through them in displaced (sometimes supernatural) form" (in Yang and Healey 4).

Adolescents are characterized by extremes of emotions: they change from feeling euphoria to being depressed, shuttling back and forth between everything (Rodabaugh 70). What they love today, they may hate tomorrow. Gothic literature is full of contrasts represented in the extremes of love and hate, of good and evil, of black and white, of light and darkness which also mirror the teenagers' perception of the world.

Gothic literature also represents the "journey" of the hero "in the quest for metaphysical and moral absolutes" (70), and the teenagers -midway between childhood and adulthood- are also searching for the absolutes, involving again the extremes. In the transition from childhood towards adulthood they try to discover their own identity while undergoing physical, psychological, emotional as well as intellectual changes.

Related to the journey of self-revelation is the concept of the individual against the unknown. In Gothic literature the unknown is represented by the dark landscapes, the mysterious architecture and the supernatural component. All what is beyond the sight or the understanding, hidden in the dark or out of control is unknown and perceived as a menace: "Adolescents too find themselves on the edge of the unknown" (70), which is adulthood: "Unsure of where they're coming 
from and where they're headed, they may easily relate the aspects of Gothic literature which highlights this journey to the unknown" (70). The representation of the hero who challenges the unknown by trying to overcome his fears may encourage teenagers to face the unexplored world of their lives.

Rebellion against the authority or the established conventions is also part of their development into adulthood. They have to develop an identity, independent from their parents and family and a capacity for independent decision-making. They experiment with and use rebellion to test the boundaries of their freedom and struggle against what they feel unfair. They share this with Gothic literature, where the rebellion of the hero represents a rebellion against the society and the norm, also depicted in the gothic sublime landscapes where the decaying architecture is a symbol of aristocratic standing and powers. Decadence embodies the rebellion against those powers as it represents the decay and the corruption of morality. Both Gothic hero(in)es and adolescents rebel against any type of authority to obtain freedom or to affirm their identities.

To affirm his/her personality a teenager needs to be accepted by his/her peers, but sometimes if the acceptance, no matter how small it is, does not occur, the adolescent may feel like an outcast. This is why they sympathize with the outcast of the Gothic literature like the monster in Frankenstein or Hyde as opposed to the Jekyll figure, or with other "attractive" outcasts such as Heathcliff, or Jane Eyre...

To sum up, adolescents are trying to figure out their place in the world, they long to be accepted by their friends and acquaintances of similar age groups, future adults like themselves; they are forming their own identities and are often in conflict with the status quo rules and conventions and mores. They feel alone, and like outcasts/monsters, they want to be themselves, but they fear their peers may no longer accept them, so they often pretend to be someone else. In this regard they often sympathize with Gothic protagonists. Adolescents are going through a lot of physical, psychological and emotional changes, which affect their bodies as well as their relationships with their peers, adults and the world in general. The Gothic genre offers them the chance to process what they are going through by helping them to go deeper into their feelings and thinking. Adolescents enjoy reading literature that reflects the depths of their emotions and, in doing so, they feel "motivated to learn the language if they feel their own world is represented in front of them" (Demetriou and Ruiz Mas 91). The use of fiction in the English language classroom implies the involvement of motivational sources for pedagogical activities and to engage learners intellectually, emotionally and linguistically by offering a picture of another culture. 
The choice of a Gothic graded reader by our EFL students also finds its justification in the internalisation that gothic forms underwent at the end of the nineteenth century. They represented the most significant shift in the genre and the gloom and darkness of sublime landscapes became external markers of inner mental and emotional states. Easy target for satire, the early Gothic romances, on the contrary, died of their own extravagances of plot, even though Gothic atmospheric machinery continued to haunt fiction. Stevenson's The Strange Case of Dr Jekyll and Mr Hyde is an example of late-gothic fiction which, beneath the surface, offers a narrative of legal philosophy as much as a story of suspense and horror. From the first pages it emerges to be more than a monster or a mystery story. It goes into the nature of the human condition showing the mental illness of the split or multiple personalities, foretelling what later Sigmund Freud and the psychoanalysis called the dissociative identity disorder (Arntfield 137). Crimes, investigation and jurisprudence are also new issues which distinguish Stevenson's novel from the extravagant and often absurd early Gothic romances.

This also justifies the election of Stevenson's novel, as, through the main theme of the double identity, it provides plenty of opportunities to tackle a lot of teenager-related issues.

\section{Conclusion}

This article cannot hide its intention to encourage teachers of secondary education to use English literature in the foreign language classroom. I intend to be some awareness-rising boost to those English secondary school teachers who are still reluctant to introduce literature in their language classroom. Literature is not a separate element but it is part of the language learning and teaching process as it is the cultural and the artistic manifestation characterizing the English civilization, their life style, ideas and values. Literature is not just reading texts, but a bridge to provide a cultural background of its speakers. Teaching English through Gothic literature may seem "strange", but it should not. I have tried to illustrate that literature, on the contrary, may provide a huge amount of useful material which can be exploited in many multicoloured and multifaceted ways, as far as the imagination is able to go, "the sky is the limit" in the immeasurable possibilities that literature can offer.

In a nutshell, literature provides a genuine, authentic sample of language, real sample of a wide range of styles, text types and registers and learners need to be trained in a variety of registers, style and genres to discern the function of each of them. Literary texts have multiple interpretations motivating an interaction with 
the text (Widdowson 1983, cited in Agustín Llach 9). By interacting and communicating a language is learned. The learner becomes active, autonomous and central in the learning process. Literary texts also show the writers' feelings that the learner can identify with and this generates a powerful motivation. Literature has a strong motivating power due to its calling on to personal experience.

Teaching English through Gothic literature should not be "strange" anymore; it should be "commonplace". I found the "commonplace" in Gothic fiction and most particularly in Stevenson's fiction, both of which have provided me with an inestimable amount of material to be adapted to the TESL/TEFL context. Students easily identify themselves with the characters and the universe offered by literature and so they "feel motivated to learn the language if they see that their own world is represented in front of them" (Demetriou and Ruiz Mas 91).

\section{WORKS CITED}

Agustin Llach, Pilar. "Teaching Language through Literature: Designing Appropriate Classroom Activities". Odisea 8, 2007. 7-17.

Arntfield, Michael. Gothic Forensics. Criminal Investigative Procedure in Victorian Horror \& Mystery. London, Ontario: Palgrave Macmillan, 2016. 135-160. DOI: https://doi.org/10.1057/978-1-137-56580-8 7

Banegas, Dario Luis. "The Role of Literature in ELT. In: Meeting the Boy in the Stripped Pyjamas". Bariloche: ELT APISALZ Forum, 2009. 1-4.

Botting, Fred. Gothic. London: Routledge, 1996.

Brumfit, C. J. "Reading Skills and the Study of Literature in a Foreign Language." Literature and Language Teaching. Eds. Christopher J. Brumfit and Ronald A. Carter. Oxford: OUP, 1986.

Caon, Fabio and Camilla Spaliviero. Educación linguistica, letteraria, intercultural: intersezioni. Torino: Bonacci Editore, 2015.

Council of Europe. Common European Framework of Reference for Languages: Learning, Teaching, Assessment. Strasbourg: Cambridge University Press, 2001.

Demetriou, Eroulla and Jose Ruiz Mas. Child's Play. An Introduction to Children's Literature for Teachers of English as a Foreign Language. Granada: GEU, 2009.

Fenner, Anne-Brit. "Dialogic Interaction with Literary Texts in the Lower Secondary Classroom". Cultural Awareness and Language Awareness Based on Dialogic Interaction with Texts in Foreign Language Learning. Ed. Anne-Brit Fenner. Strasbourg: Council of Europe, 2001. 14-46. 
Giusti, Simone. Insegnare con la letteratura. Roma: Congresso ADI-SD, 2011.

Littlewood, William T. "Literature in the School Foreign-Language Course". Literature and Language Teaching. Eds. Christopher J. Brumfit and Ronald A. Carter. Oxford: OUP, 1986.

McKay, Sandra. "Literature in the ESL Classroom." Literature and Language Teaching. Eds. Christopher J. Brumfit and Ronald A. Carter. Oxford: OUP, 1986.

Rodabaugh, Wendy L. "Teaching Gothic Literature in the Junior High Classroom." The English Journal, vol. 85, no. 3 (Mar. 1996). 68-73. DOI: https://doi.org/10.2307/820110

Yang, Sharon Rose, and Kathleen Heley. "Introduction." Gothic Landscapes. Changing Eras, Changing Cultures, Changing Anxieties. Worcester: Palgrave Mcmillan, 2016. 1-18.

Weldon, Fay. Letter to Alice on First Reading Jane Austen. London: Sceptre, 1993. 
